\title{
ERG Gene Rearrangement Negative
}

National Cancer Institute

\section{Source}

National Cancer Institute. ERG Gene Rearrangement Negative. NCI Thesaurus. Code C160358.

A genetic finding indicating that rearrangement of the ERG gene has not been detected in a sample. 